\title{
Supervision in Healthcare: A Critical Review of the Role, Function and Capacity for Training
}

\author{
Daniel Terry $^{1, *}$, Hoang Nguyen ${ }^{2}$, Alicia J Perkins ${ }^{1}$, Blake Peck ${ }^{1}$ \\ ${ }^{1}$ School of Nursing and Healthcare Professions, Federation University Australia, Australia \\ ${ }^{2}$ Wicking Dementia Research and Education Centre, University of Tasmania, Australia
}

Received October 19, 2019; Revised December 3, 2019; Accepted December 10, 2019

Copyright $(2020$ by authors, all rights reserved. Authors agree that this article remains permanently open access under the terms of the Creative Commons Attribution License 4.0 International License

\begin{abstract}
This paper examines the notion of clinical supervision and takes a close look at what it means from the perspective of both the supervisee and the supervisor, considering how it can be of benefit to the learner, the teacher and the patient. Clinical supervision has been shown to be vital for the development and consolidation of undergraduate and postgraduate education, while having a positive impact on patient outcomes and as such is a fundamental component in healthcare education. Central to supervision is achieving the best outcomes for the supervisee, and effective supervision ensures the development of confidence, professional identity, and the consolidation of therapeutic knowledge. Clinical supervision provides a platform for extending the supervisor-supervisee relationship beyond the student-teacher model to one of mutual personal development in contemporary knowledge and skills for clinical practice. Despite the perceived importance of clinical supervision for healthcare more broadly, there is evidence to suggest that few supervisors are adequately prepared with the theory and practice of clinical supervision to adequately fulfill the expectations that the role entails. It follows therefore, that in many cases, there is an expectation that the health professionals will supervise without adequate preparation. This paper, although not a panacea, may assist those who are supervising and who seek or require some guidance and support.
\end{abstract}

Keywords Education, Healthcare, Mentor, Role model, Student, Supervision

\section{Introduction}

Before we can begin to unpack the nuances of clinical supervision for effective implementation, it is essential to understand what is meant by supervision in healthcare, and the many differing names, definitions, functions and models. At the centre of this still unsettled nature of supervision, as an entity, is a recognition that supervision is one of the least developed facets of education, having only a limited empirical or theoretical basis.[1-3] While the term 'clinical supervision' adopts many aspects of precepting and mentoring, and is often used interchangeably, the roles or models of supervision are quite different.

Within the literature, definitions of supervision have evolved both within higher education and within healthcare.[4-13] For example, supervision has been described as either a one-way process or a two-way process with joint endeavour, consultation, working alliance at its core.[14-18] Further, it is often outlined to be a formal activity for professional development and learning where there is an emphasis on discussion, feedback, guidance and support with the aim of enhancing the functionality, quality, and capability or effectiveness of the supervisee.[14-18]

Looking beyond the definition, to the models of supervision - particularly those in medicine - it is evident that the apprenticeship model remains dominant. As such, this model is framed by "a clinical apprenticeship of the novice to the master craftsman".[19] It is where a more experienced health professional guides and ensures that the subordinate or less experienced supervisee is exposed to and provided with opportunities to develop their clinical competence, to become more independent in practice.[20,21]

However, others challenge the apprenticeship model and suggest that it is inconsistent with the principles of adult-learning theory and sociocultural learning, that are founded on theories of applied learning with an emphasis on isolated experiential learning and reflective practice.[19] The lack of emphasis on adult learning principles in the apprenticeship model means that training physicians receive limited or no training in this area, a 
finding that Senediak and Bowden [22] attribute in part to concerns that the incorporation of these best-practice approaches to teaching and learning might expose the current apprenticeship model as being less than the gold standard.

As well as those in medicine, other models of supervision can be found in literature from other discipline areas such as nursing, social work, and counselling.[2-10] For example, there are models such as 'narrative-based supervision', 'incidental supervision' and 'peer supervision' each of which has their own idiosyncrasies. All of this would suggest that definitional consistency and models of supervision - even within each health discipline - remains elusive.

To fully appreciate the diverse nomenclature, definitions and models of supervision in healthcare, a critical review of the literature sought to identify and examine supervision definitions and models.[23] As such, the aim of this review to examine the notion of clinical supervision and what supervision means from the perspective of both the supervisee and the supervisor, considering how it can be of benefit to the learner, the teacher and the patient.

\section{Materials and Methods}

\subsection{Search Strategy}

A broad literature search was conducted in March 2019, using Medline, CINAHL, PsycINFO, Informit, JSTOR, Science Direct, Scopus and Web of Science databases to identify supervision definitions and models used in literature discussing supervision within healthcare professions including nursing, allied health and medicine between 1999 and 2019. The databases were accessed using title, keyword, or abstract and then full-text. Search terms included "Healthcare" AND "Supervision" OR "Preceptor" OR "Apprentice" OR "Mentor" including word suffixes. This strategy was used to search title and abstract in all databases and was adapted to the specific requirements of each database. Additional searches of literature were conducted by hand searching or reviewing reference lists.

\subsection{Inclusion and Exclusion Criteria}

The reviewed studies included those that were original research or peer reviewed commentaries on the subject. Inclusion included both internal and external to the acute hospital settings and included all healthcare professions where the supervisee was a student or novice healthcare professional. Studies were excluded if their focus was solely on program evaluations, measuring the efficacy or impact of supervision models, or were discussions informing government policy. However, studies were included if they focussed on seeking or discussing supervision taxonomy, models and their relative strengths and weaknesses. Full-text articles published in languages other than English were not reviewed given the issues associated with translation qualities.

\subsection{Study Screening}

The articles retrieved from the search were exported to EndNote (version X7) and screened by two reviewers (DT and BP) after duplicates were removed. Both reviewers independently screened all studies based on titles, keywords and abstracts to exclude irrelevant articles. In the second round, full text articles were assessed independently and judged against the inclusion and exclusion criteria by two reviewers (DT and BP). Each study was classified as 'include', 'exclude' or 'not sure' in the review. Any discrepancies between the two reviewers were resolved by discussion with a third reviewer (AP) until consensus was achieved.

\section{Results}

The literature search resulted in a total of 5,779 records. After 791 duplicates were removed, there were 4,988 potentially relevant records. The subsequent title and abstract screening led to the exclusion of 4,781 records. A total of 207 full-text articles were assessed for eligibility against the inclusion and exclusion criteria, resulting in 149 studies being further excluded. Finally, 58 original research studies were included where the necessary data were available. The majority of studies focussed on Nursing $(\mathrm{n}=26)$ and Medicine $(\mathrm{n}=22)$ followed by Psychiatry $(\mathrm{n}=4)$, Physiotherapy $(\mathrm{n}=2)$, Social work $(\mathrm{n}=1)$, Pharmacy $(\mathrm{n}=1)$, and Occupational therapy $(\mathrm{n}=1)$, with the remaining examining supervision in non-specific Allied Health professions $(\mathrm{n}=2)$, as outlined in Figure 1.

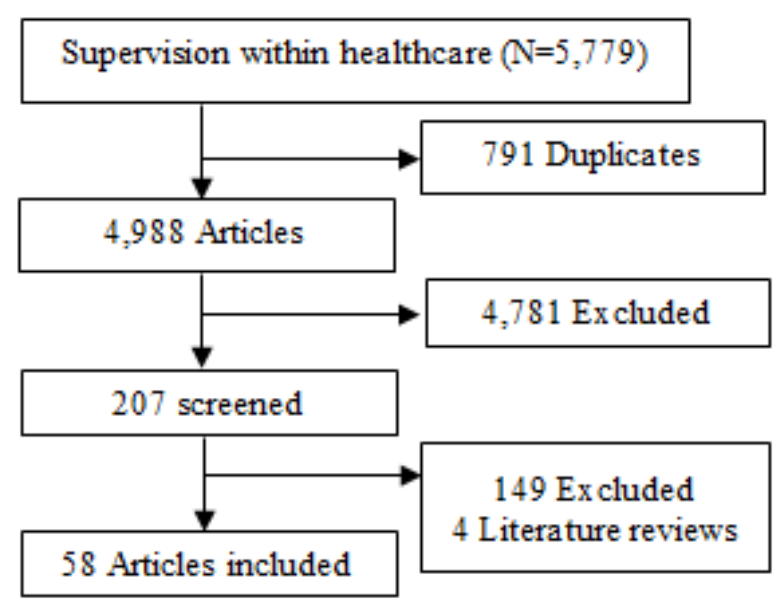

Figure 1. Literature search results 
Table 1. Contemporary definitions of supervision

\begin{tabular}{|c|c|c|c|c|}
\hline Authors, Year & $\begin{array}{l}\text { Description or } \\
\text { Conceptualisation }\end{array}$ & People and Setting & Focus, Method and Process & Aims, Goals \\
\hline $\begin{array}{l}\text { (Bernard \& Goodyear, } \\
\text { 2008) [4] }\end{array}$ & An intervention & $\begin{array}{l}\text { Provided by senior members of a } \\
\text { profession to a more junior } \\
\text { members of the same profession }\end{array}$ & Is evaluative and extends over time & $\begin{array}{l}\text { To enhance the professional functioning of the more junior } \\
\text { person(s), monitoring the quality of professional services } \\
\text { offered to the clients, and gatekeeping those who enter the } \\
\text { profession }\end{array}$ \\
\hline $\begin{array}{l}\text { (Barker, 2006; Cutcliffe \& } \\
\text { Butterworth. 2001) }[5,6]\end{array}$ & $\begin{array}{l}\text { A formal process of } \\
\text { professional support and } \\
\text { learning }\end{array}$ & To enable individual clinicians & - & $\begin{array}{l}\text { To develop knowledge and competence and assume } \\
\text { responsibility for their own practice }\end{array}$ \\
\hline $\begin{array}{l}\text { (Hancox \& Lynch, 2002) } \\
\text { [7] }\end{array}$ & $\begin{array}{l}\text { A formal process of } \\
\text { consultation }\end{array}$ & Between two or more professionals & To provide support for the supervisees & $\begin{array}{l}\text { To promote self-awareness, professional development and } \\
\text { growth in their professional environment }\end{array}$ \\
\hline $\begin{array}{l}\text { (Hawkins, Shohet, Ryde, } \\
\& \text { Wilmot, 2012) [8] }\end{array}$ & A joint endeavour & $\begin{array}{l}\text { A supervisor will help a supervisee } \\
\text { attend to their clients the wider } \\
\text { healthcare context }\end{array}$ & - & $\begin{array}{l}\text { To improve the quality of student's/novice's work and develop } \\
\text { their practice and the wider profession }\end{array}$ \\
\hline $\begin{array}{l}\text { (Chaves et al., 2017; } \\
\text { Inskipp \& Proctor, 2001) } \\
{[9,10]}\end{array}$ & A working alliance & Between supervisor and supervisee & $\begin{array}{l}\text { Supervisee accounts or records their } \\
\text { work; reflects on it; receive feedback } \\
\text { and guidance }\end{array}$ & $\begin{array}{l}\text { To enable supervisees to gain competence, confidence, } \\
\text { compassion and creativity to give their service to the client. }\end{array}$ \\
\hline $\begin{array}{l}\text { (Kilminster \& Jolly, 2000) } \\
\text { [2] }\end{array}$ & $\begin{array}{l}\text { Provision of monitoring, } \\
\text { guidance and feedback }\end{array}$ & In the context of patient care & $\begin{array}{l}\text { The ability to anticipate strengths and } \\
\text { weaknesses in clinical situations }\end{array}$ & Too maximize patient safety \\
\hline $\begin{array}{l}\text { (Martin, Kumar, \& } \\
\text { Lizarondo, 2017) [59] }\end{array}$ & $\begin{array}{l}\text { A formal professional support } \\
\text { process that is structured and } \\
\text { planned. }\end{array}$ & $\begin{array}{l}\text { Involves a supervisor and a } \\
\text { supervisee in the workplace }\end{array}$ & $\begin{array}{l}\text { Involves evaluation, reflective } \\
\text { thinking and discussion about } \\
\text { professional development, clinical } \\
\text { issues and interpersonal issues } \\
\text { encountered }\end{array}$ & To assist with the skill development of the supervisee \\
\hline $\begin{array}{l}\text { (Fernandez, } \\
\text { Sheppard-Law, Curtis, } \\
\text { Bancroft, \& Smith, 2018; } \\
\text { Hesketh \& Laidlaw, 2003; } \\
\text { Milne, 2007) [11-13] }\end{array}$ & $\begin{array}{l}\text { A mutually beneficial } \\
\text { education relationship based on } \\
\text { trust, communication, respect } \\
\text { and cultural influences }\end{array}$ & $\begin{array}{l}\text { By approved supervisors, and work } \\
\text { focussed }\end{array}$ & $\begin{array}{l}\text { Uses corrective feedback on } \\
\text { performance, teaching, and } \\
\text { collaborative goal-setting }\end{array}$ & $\begin{array}{l}\text { To manage, support, develop and evaluate colleagues. } \\
\text { The objectives are about quality control, encouraging emotional } \\
\text { processing, and maintaining and facilitating competence, } \\
\text { capability and effectiveness. }\end{array}$ \\
\hline $\begin{array}{l}\text { (Hilli, Melender, Salmu, } \\
\text { \& Jonsen, 2014) [60] }\end{array}$ & $\begin{array}{l}\text { A caring relationship as the } \\
\text { foundation for student learning }\end{array}$ & Between supervisor and supervisee & $\begin{array}{l}\text { Not only a cooperative relationship, } \\
\text { but also has an ethical dimension. } \\
\text { Needs to be a supportive environment } \\
\text { for both the students and preceptors. }\end{array}$ & $\begin{array}{l}\text { The focus is more than technical skills, but is an opportunity to } \\
\text { learn personal skills in clinical judgement and ethical aspects of } \\
\text { nursing. }\end{array}$ \\
\hline $\begin{array}{l}\text { (Carlson, Pilhammar, \& } \\
\text { Wann-Hansson, 2010; } \\
\text { O'Keeffe \& James, 2014) } \\
{[39,61]}\end{array}$ & $\begin{array}{l}\text { Role modelling of the } \\
\text { profession }\end{array}$ & $\begin{array}{l}\text { Involves a professional in as a } \\
\text { supervisor and a supervisee in the } \\
\text { workplace }\end{array}$ & ( & $\begin{array}{l}\text { To develop 'competence, creativity, confidence and } \\
\text { compassion' and benefits patient care. Other objectives are } \\
\text { frequently included within the scope of professional } \\
\text { supervision. }\end{array}$ \\
\hline $\begin{array}{l}\text { (Chun, Sosik, \& Yun, } \\
\text { 2012; Pack, 2009) [21, 45] }\end{array}$ & A developmental process & $\begin{array}{l}\text { The supervisee learns the skills and } \\
\text { confidence from supervisor }\end{array}$ & $\begin{array}{l}\text { A more experienced mentor and a less } \\
\text { experienced protégé are matched }\end{array}$ & $\begin{array}{l}\text { To increase independence and to share organizational } \\
\text { knowledge and career advancement. }\end{array}$ \\
\hline $\begin{array}{l}\text { (Senediak \& Bowden, } \\
2007) \\
{[22]}\end{array}$ & A reflective practice & Between supervisor and supervisee & $\begin{array}{l}\text { Competency-based with a focus on } \\
\text { skill } \\
\text { development }\end{array}$ & $\begin{array}{l}\text { To develop competent trainees and enhance clinical care, } \\
\text { independence and ongoing development of skills and } \\
\text { knowledge, with a commitment to life-long learning. }\end{array}$ \\
\hline
\end{tabular}


Table 2. Supervision models in healthcare

\begin{tabular}{|c|c|c|c|c|c|}
\hline Author & Model & Discipline & Approach & Strengths & Weaknesses \\
\hline $\begin{array}{l}\text { (Launer, 2013; Morrison \& } \\
\text { Halpern, 2012a) } \\
{[14,15]}\end{array}$ & $\begin{array}{l}\text { Narrative-based } \\
\text { supervision }\end{array}$ & Medicine & $\begin{array}{l}\text { A method for discussing complex and } \\
\text { challenging medical cases with peers and } \\
\text { trainees }\end{array}$ & $\begin{array}{l}\text { Less prescriptive, unstructured, } \\
\text { can be one-to-one or as a group. } \\
\text { Can include the patient. }\end{array}$ & $\begin{array}{l}\text { Less defined. Supervision means any } \\
\text { conversation between professionals } \\
\text { aimed at improving clinical care }\end{array}$ \\
\hline $\begin{array}{l}\text { (Undrill, 2012) } \\
\text { [62] }\end{array}$ & Incidental supervision & Medicine & $\begin{array}{l}\text { A flexible and opportunistic method of } \\
\text { supervision that is and imbedded within } \\
\text { practise. It has immediate impact without } \\
\text { impacting clinical practise. Can be used in } \\
\text { one-on-one and groups supervision. }\end{array}$ & $\begin{array}{l}\text { Needs to be well structured using } \\
\text { a formalised approach and used } \\
\text { by those with skill and experience. }\end{array}$ & $\begin{array}{l}\text { Can be difficult to recognise as more } \\
\text { than being told what to do. Need to } \\
\text { ensure it is adequately provided in } \\
\text { meaningful way. }\end{array}$ \\
\hline $\begin{array}{l}\text { (Andersen et al., 2019; } \\
\text { Kalisch, Falzetta, \& Cooke, } \\
\text { 2005; Miller, Miller, Burton, } \\
\text { Sprang, \& Adams, 2003) } \\
\text { [16-18] }\end{array}$ & $\begin{array}{l}\text { Telehealth supervision, } \\
\text { Tele-mentoring, } \\
\text { e-mentoring }\end{array}$ & $\begin{array}{l}\text { Medicine Allied } \\
\text { Health } \\
\text { Psychology } \\
\text { Nursing }\end{array}$ & $\begin{array}{l}\text { A sustainable method for supervision } \\
\text { among supervisees who are in rural and } \\
\text { remote regions achieved through video } \\
\text { link, email and other web based methods }\end{array}$ & $\begin{array}{l}\text { Requires more formalised } \\
\text { approach and set agendas. Can be } \\
\text { achieved one-to-one or as a group } \\
\text { and multidisciplinary. }\end{array}$ & $\begin{array}{l}\text { Issues with technology and lack of } \\
\text { personal contact or reduced time with } \\
\text { supervisor }\end{array}$ \\
\hline $\begin{array}{l}\text { (Lekkas et al., 2007; } \\
\text { Morrison \& Halpern, 2012b; } \\
\text { Tulinius, 2013) } \\
\text { [63-65] }\end{array}$ & $\begin{array}{l}\text { Peer supervision } \\
\text { Balint method } \\
\text { Reflecting teams }\end{array}$ & $\begin{array}{l}\text { Medicine } \\
\text { Allied health }\end{array}$ & $\begin{array}{l}\text { Groups are focused on professional } \\
\text { development, group sessions provide a } \\
\text { systematic approach to the practice, based } \\
\text { on a challenge or question that has created } \\
\text { uncertainty in a group member. Groups are } \\
\text { often geographically demarcated. }\end{array}$ & $\begin{array}{l}\text { Focused around continuous } \\
\text { discussion, social networking, and } \\
\text { addressing uncertainty or an } \\
\text { identified need. }\end{array}$ & $\begin{array}{l}\text { A fluid process that is less } \\
\text { systematic. Relies on uncertainty to } \\
\text { facilitate learning, but does have } \\
\text { provision for more systematic } \\
\text { approach to learning. }\end{array}$ \\
\hline $\begin{array}{l}\text { (Davis, 2006; Kilminster \& } \\
\text { Jolly, 2000) } \\
{[2,66]}\end{array}$ & $\begin{array}{l}\text { Client focused (or } \\
\text { centred) supervision }\end{array}$ & $\begin{array}{l}\text { Social work } \\
\text { Occupational } \\
\text { Health }\end{array}$ & $\begin{array}{l}\text { Supervisors take on a facilitator role and } \\
\text { trusts students to take responsibly for their } \\
\text { own learning }\end{array}$ & Needs to be well structured. & $\begin{array}{l}\text { Gaps in knowledge or impact on } \\
\text { patient care may be challenging }\end{array}$ \\
\hline $\begin{array}{l}\text { (Severinsson, 1999) } \\
\text { [67] }\end{array}$ & $\begin{array}{l}\text { Ethical-oriented } \\
\text { supervision models }\end{array}$ & Nursing & $\begin{array}{l}\text { Model is a combination of management } \\
\text { and counselling. Supervisees identify a } \\
\text { problem, select relevant information, set } \\
\text { priorities, develop action plan, analyse } \\
\text { reactions, and evaluate strategies in the } \\
\text { ethical decision-making process. }\end{array}$ & $\begin{array}{l}\text { Can be quite defined, and } \\
\text { although based on reflection and } \\
\text { past practice remains theoretical. } \\
\text { Focus is the development of } \\
\text { cognitive skills. }\end{array}$ & $\begin{array}{l}\text { Must have knowledge base and } \\
\text { clinical standards to which profession } \\
\text { must uphold }\end{array}$ \\
\hline $\begin{array}{l}\text { (Severinsson, 1999; Stainsby } \\
\& \text { Bannigan, 2012) } \\
{[67,68]}\end{array}$ & In-direct supervision & $\begin{array}{l}\text { Nursing } \\
\text { Medicine } \\
\text { Allied health }\end{array}$ & $\begin{array}{l}\text { Supervision or clinical observations are } \\
\text { made by the supervisees, who later discuss } \\
\text { their clinical experiences with supervisors } \\
\text { who may or may not be on-site at all times. }\end{array}$ & Needs to be well structured. & $\begin{array}{l}\text { Less defined, and may be } \\
\text { problematic to resolve issues } \\
\text { immediately. Gaps in knowledge of } \\
\text { supervisor/supervisee may impact } \\
\text { learning or patient care. }\end{array}$ \\
\hline $\begin{array}{l}\text { (Lekkas et al., 2007; } \\
\text { Overton, Clark, \& Thomas, } \\
\text { 2009; Stainsby \& Bannigan, } \\
2012 \text { ) } \\
{[65,68,69]}\end{array}$ & $\begin{array}{l}\text { Long-arm or } \\
\text { role-emerging supervision }\end{array}$ & Allied Health & $\begin{array}{l}\text { Off-site supervisors from the profession } \\
\text { meet and discuss with supervisee regarding } \\
\text { clinical experiences or practice only a few } \\
\text { hours a week. On-site supervisors are from } \\
\text { another health profession and assist with } \\
\text { non-profession specific support. Additional } \\
\text { profession-specific support may be } \\
\text { provided. }\end{array}$ & $\begin{array}{l}\text { Independence and autonomy of } \\
\text { supervisees. Needs to be very well } \\
\text { structured. Key goals and } \\
\text { objectives delineated to ensure } \\
\text { learning is achieved. }\end{array}$ & $\begin{array}{l}\text { May be problematic to resolve issues } \\
\text { immediately. Gaps in knowledge of } \\
\text { on-site supervisor may impact } \\
\text { learning or patient care. May not be } \\
\text { suitable for novice supervisees. Cost } \\
\text { may be prohibitive. }\end{array}$ \\
\hline
\end{tabular}




\begin{tabular}{|c|c|c|c|c|c|}
\hline $\begin{array}{l}\text { (Franklin, 2013; Franklin, } \\
\text { Leathwick, \& Phillips, 2013) } \\
{[70,71]}\end{array}$ & $\begin{array}{l}\text { Preceptor model } \\
\text { One-to-one model } \\
\text { Group model }\end{array}$ & $\begin{array}{l}\text { Nursing } \\
\text { Allied Health }\end{array}$ & $\begin{array}{l}\text { Supervisee or a group is assigned to a } \\
\text { Supervisor. The supervisee(s) works } \\
\text { alongside the supervisor day-to-day to } \\
\text { provide direct and indirect supervision. } \\
\text { Formative and summative assessments } \\
\text { undertaken. }\end{array}$ & $\begin{array}{l}\text { Defined roles and structures in } \\
\text { place. Novice supervisees favour } \\
\text { preceptor model. }\end{array}$ & $\begin{array}{l}\text { Outcomes dependant on supervisor's } \\
\text { clinical knowledge, skills and attitude } \\
\text { towards supervisees. Increased clinic } \\
\text { workload and time. }\end{array}$ \\
\hline $\begin{array}{l}\text { (Borch, Athlin, Hov, \& } \\
\text { Sörensen Duppils, 2013; } \\
\text { Franklin, 2013; Franklin et } \\
\text { al., 2013) } \\
\text { [70-72] }\end{array}$ & $\begin{array}{l}\text { Facilitator or Group } \\
\text { Model } \\
\text { One-to-one model } \\
\text { Group model }\end{array}$ & Nursing & $\begin{array}{l}\text { Supervisee or a group is assigned to a } \\
\text { Supervisor. The supervisee(s) works in } \\
\text { conjunction with the supervisor and is } \\
\text { provided more direct (one-on-one) and } \\
\text { indirect supervision. Supervisor can be } \\
\text { employed on casual basis and work across } \\
\text { health facilities and in tertiary education. }\end{array}$ & $\begin{array}{l}\text { Defined roles and structures in } \\
\text { place. More proficient supervisees } \\
\text { favour facilitator model. Better } \\
\text { approach to link theory to practice } \\
\text { and to reduce cost. }\end{array}$ & $\begin{array}{l}\text { Outcomes dependant on supervisor's } \\
\text { clinical knowledge, skills and attitude } \\
\text { towards supervisees. More novice } \\
\text { supervisees may be less suitable. }\end{array}$ \\
\hline $\begin{array}{l}\text { (Senediak \& Bowden, 2007). } \\
\text { [22]. }\end{array}$ & Apprenticeship model & $\begin{array}{l}\text { Medicine } \\
\text { Allied Health }\end{array}$ & $\begin{array}{l}\text { Direct supervision with supervisee } \\
\text { practising skills and performing tasks } \\
\text { within an established supervisor }\end{array}$ & $\begin{array}{l}\text { Defined roles and structures in } \\
\text { place. Direct supervision of } \\
\text { challenging or difficult } \\
\text { supervisees. Essential for } \\
\text { beginning or novice }\end{array}$ & $\begin{array}{l}\text { Remains problematic if supervisee is } \\
\text { situated in 'non-traditional' settings } \\
\text { where health profession is not } \\
\text { normally situated. May create } \\
\text { reliance and dependency. }\end{array}$ \\
\hline $\begin{array}{l}\text { (Finnerty \& Collington, } \\
\text { 2013) } \\
{[73]}\end{array}$ & $\begin{array}{l}\text { Cognitive Apprenticeship } \\
\text { model }\end{array}$ & Midwifery & $\begin{array}{l}\text { Traditional models emphasise practical } \\
\text { visibility of skills whilst cognitive models } \\
\text { emphasise deliberate activities to assist } \\
\text { thinking to surface and be made visible }\end{array}$ & $\begin{array}{l}\text { The absences of the mentor } \\
\text { initiating care and the student } \\
\text { assisting, but that mentor is a } \\
\text { mediator to demonstrate relevance } \\
\text { of formal knowledge to practice. }\end{array}$ & $\begin{array}{l}\text { Is focused on enhancing the } \\
\text { development and higher cognitive } \\
\text { abilities of learners. May be } \\
\text { challenging for some students. }\end{array}$ \\
\hline $\begin{array}{l}\text { (Franklin, 2013; Franklin et } \\
\text { al., 2013; Hesketh \& } \\
\text { Laidlaw, 2003) } \\
{[13,70,71]}\end{array}$ & Mentor model & Nursing & $\begin{array}{l}\text { Similar to preceptor model, however, less } \\
\text { common among undergraduate } \\
\text { supervisees. Can be a direct or in-direct } \\
\text { approach }\end{array}$ & $\begin{array}{l}\text { More indirect and requires a level } \\
\text { of competency and independence } \\
\text { among supervisees. }\end{array}$ & $\begin{array}{l}\text { Requires longer term relationship } \\
\text { between parties. Not well suited to } \\
\text { short term supervision or } \\
\text { undergraduates. }\end{array}$ \\
\hline $\begin{array}{l}\text { (Aston \& Molassiotis, 2003) } \\
\text { [74] }\end{array}$ & $\begin{array}{l}\text { Peer support supervision } \\
\text { model }\end{array}$ & Nursing & $\begin{array}{l}\text { Senior students supervise and support } \\
\text { junior students in clinical placement, while } \\
\text { being overseen by clinical mentor }\end{array}$ & $\begin{array}{l}\text { Uses communities of practice } \\
\text { approach to supervision. Develops } \\
\text { the senior and junior student } \\
\text { capacity }\end{array}$ & $\begin{array}{l}\text { Requires clinical mentor who is } \\
\text { engaged with the process and address } \\
\text { issues at short notice. Increased } \\
\text { levels of responsibility among senior } \\
\text { students. The capacity for poor } \\
\text { performance/skills to remain } \\
\text { unchecked. }\end{array}$ \\
\hline $\begin{array}{l}\text { (Russell, Hobson, \& Watts, } \\
\text { 2011) } \\
{[75]}\end{array}$ & Team Leader Model & Nursing & $\begin{array}{l}\text { Teams of three: a registered nurse as } \\
\text { 'Team Leader' and supervisor, an } \\
\text { undergraduate student and the third being a } \\
\text { staff member who would benefit from } \\
\text { additional support, such as graduate nurse }\end{array}$ & $\begin{array}{l}\text { Uses communities of practice } \\
\text { approach to supervision. Develops } \\
\text { the novice and student capacity }\end{array}$ & $\begin{array}{l}\text { Requires clinical mentor to be } \\
\text { engaged with the process and address } \\
\text { issues at short notice. Increased } \\
\text { levels of responsibility for novice. }\end{array}$ \\
\hline
\end{tabular}


Within the literature each definition of supervision was captured and is outlined in Table 1. Despite the diversity, for the purpose of this paper, the definition by Bernard and Goodyear [4] which has been widely accepted, is adopted to underpin the discussion of supervision.

An intervention provided by a more senior member of a profession to a more junior member or members of that same profession. This relationship is evaluative, extends over time, and has the simultaneous purposes of enhancing the professional functioning of the more junior person(s), monitoring the quality of professional services offered to the clients... [Supervisors are] serving as a gatekeeper for those who are to enter the particular profession. (p. 8)

In addition to the definition, the models of supervision are outlined in Table 2, highlight the type, strengths and limitations of each supervision approach, and confirms the apprenticeship model remains dominant, as previously discussed and outlined in Table 2.

Despite the supervision differences that are noted between and within professions, the following analogous and fundamental aspects of supervision were identified within the literature. These themes included the dynamic nature of the supervisory relationship; the challenges, recommendations, and actions for supervisors; the required elements of supervision, which include awareness, planning, communication, and modelling. Additional themes encompass moving from direct instruction to self-directed learning, which involves review, feedback and reflective practice, and are all discussed in detail.

\subsection{The Dynamic Nature of the Supervisory Relationship}

Although much of the available literature tends to focus on the 'best case scenario', supervision is a dynamic entity open to its inherent challenges. Pack ${ }^{7}$ identified that some of the more prevalent challenges include conflicts or 'clashes' between the personalities, and challenges to established and perhaps forming boundaries between the supervisor and supervisee that may at times involve the patient. Compounding this may be the hierarchical structures of the organisation as well as the differing expectations of the supervisory role that each party has. For example, supervisees may anticipate supervision as an educational and well supportive process, while supervisors may consider supervision being centred on novice inexperience and dependence. As such, Pack [21] suggested that the role of the supervisor, particularly in medicine, can and has led to the "pathologising of the supervisee".[21] This has resulted in the view that supervisees may be ill-equipped, regressive and dependant, with subsequent restrictions or reductions in supervisor feedback.[24]

The dynamics of the supervisory relationship are also mediated by elements that may be considered external to the relationship, but have implication for their effectiveness. These elements include the level of training the supervisor may have, the provision of misleading or misguided information prior to clinical placement, or a change in the circumstance of external parties which trickles down to last minute changes in supervisee or supervisor participation in the planned engagement. At the same time other elements which may have an impact include gender or cultural differences of various individuals.[6] It is these differences that may further exacerbate the supervisory encounter. For example, supervisees from different cultural backgrounds may be less likely to voice an opinion or indicate they do not understand. This can then lead to perceptions of poor knowledge or negative perceptions of the individual, or group of individuals - that they do not consult or discuss issues with the supervisor before proceeding with patient care.[21]

Another external variable that has been shown to have an effect on the supervisory relationship is the notion of timing. It is vital to recognise that as supervisees commence working with patients, they can experience anxiety regarding their own abilities or behaviours and how this may be perceived by the supervisor. It is a time of learning as the novice seeks to implement skills, learn what they are 'supposed' to do next, while interacting with and understanding the client. Despite these anxieties, beginning students and trainees are highly motivated as they are learning how to be a professional. However, as the initial anxieties abate, confidence increases, motivation is further moderated, and the autonomy of the individual further develops.[25] It is therefore poignant to work closely with and assist beginning supervisees to transition more effectively and efficiently through the period of anxiety, toward greater confidence and autonomy by harnessing their motivation and alleviating their fear.[3] Arguably it is the supervisor who has the greatest capacity to influence the relationship more broadly, however there may be some challenges.

\subsection{Challenges, Recommendations and Actions}

Clinical supervision does not occur in a vacuum, where the supervision of other staff would be the sole responsibility or concern within day-to-day practice. Instead, there are competing pressures of at times complex workloads, and the inherent costs associated with undertaking supervisory roles. At times, there may be an expectation from health facility, or registration body that some healthcare professionals will simply add the responsibility of supervision to their already under resourced roles.[12, 26] In addition, the added complexity of negotiating roles and responsibilities can leave a clinician - often a senior clinician - unsure of how to find a balance between patient care on the one hand and 
supervision of junior staff on the other. Pack [21] captures this tension:

Supervisors can feel torn between the needs of the organisation, supervisees and clients. They endeavour to function as role models to supervisees yet struggle to establish an equal relationship in the process of [clinical supervision], as they are required to exert their authority to manage them. (p.664)

It is these challenges that may impact a supervisor's view of self and their capacity to effectively and meaningfully supervise, while balancing various competing responsibilities and interests. Added to this expectation and competing demands, there is the challenge of taking on the role with little or no training regarding effective supervision.

Overall, supervisors need to ensure supervisees develop their professional selves, be competent and confident in practice, while ensuring care can and is provided safely and adequately to patients. Not surprisingly, professional training of supervisors has been shown to improve and enhance outcomes, making the investment in professional training for supervisors a fundamental step in the development of clinically proficient supervisees.[25] Formalised training is all the more crucial when we consider the consequences of its absence. For example, supervisees who come to the supervisory encounter, may do so feeling ill-prepared and being reluctant to disclose that they may lack certain knowledge. This can also lead to working in isolation, working independent of the supervisor, and without continued consultation. This has the potential to lead to clinical errors, further impacting the supervisor-supervisee relationship and have a detrimental impact on patient outcomes.[12, 21]

Colleges, universities, and professional bodies recognise the importance of supervision training and implemented formalised supervisory training.[3] It is through these opportunities that clinicians collaborate with others and share experiences and best practice. Training also provides clinicians with contemporary literature and understanding to provide an opportunity for critical reflection and evaluation of one's own practice, and gives rise to peer review or external scrutiny of supervisory practices. [25]

The challenge is that health facilities may lack the resources, motivation, policies or capacity to provide effective support and training in these areas. There is a need to develop a culture where supervision and supervisory training is considered the touchstone of good practice, while developing an environment that pursues high or higher standards of effective clinical supervision.[3] The process needs both a 'top down' and 'bottom up' approach, where health professional's work with organisations to build a commitment to allocate appropriate time and resources to improve professionals' capacity to supervise. This in turn will have an impact on supervisees and lead to better patient outcomes. $[3,27]$ As such, "the quality of clinical supervision is the key influence on the quality of the clinical placement and, ultimately, on the calibre of the health practitioner". [28]

Contemporary programs of education in Australia have led to an increasing number of healthcare professionals undergoing training to support an expanding healthcare system, with clinical practicum or work integrated learning being a key component of their preparation. Consequently, appropriate numbers of competent clinical supervisors need to be available to support students during clinical practicum, and suitable training must be available for clinical supervisors to develop and maintain their competency. In 2011, Health Workforce Australia (HWA) [29] developed the National Clinical Supervision Support Program, with a purpose to increase public trust in the education and training of health professionals, by using a coordinated and integrated approach to improve the capability and competency of clinical supervisors to effectively engage with supervisees.

The National Clinical Supervision Competency Resource [29] was subsequently established to be used both as a framework to guide and support health care providers to develop training programs in clinical supervision, and also as a tool to assess the competence of individual clinical supervisors. This placed the onus on the health service to deliver programs of education, targeting clinical supervision competency among their education teams, with the purpose being to build capacity and reform the delivery of education to trainees, and to meet future health workforce requirements across all locations and healthcare disciplines. The National Clinical Supervision Competency Resource also assists providers to identify and understand the core competencies and professional expectations of a clinical supervisor at two levels of practice: foundational and intermediate, thus providing a benchmark against which the learning needs of individual clinical supervisors, and organisation wide training requirements can be identified and assessed.[29]

\subsection{Required Elements of Supervision}

A number of key elements are required in order to develop the professional self, and to contribute to the enhancement of the supervisor-supervisee encounters.

\subsubsection{Awareness of Self and the Other}

The awareness of self and the other as a form of reflective practice factors within the supervisor-supervisee encounter, impacts on the outcomes of the overall transaction, where awareness of self and self-performance is the yard stick to measure overall development of skill and capacity to supervise, and remains at the centre of supervision.[6, 21, 30] Pack[21] further suggests a transactional analysis model is required to develop a structure and process that recognises micro level factors within a single encounter and over time. For example, the model considers the clients', supervisors' and supervisees' 
socio-economic position, work setting, class, culture and ethnicity. The wider social systems of client and supervisor-supervisee and their employing agencies can be explored within this type of multi-level approach.[21] This multi-layered approach assists supervisors to recognise and pay attention to the supervisee's practice, their workload and case mix, while being aware of their psychosocial wellbeing, and the supervisor-supervisee relationship.[21]

As a supervisor, it is vital to recognise that supervisees come with a cacophony of learning, confidence levels, life experiences, and differing world views.[31] It is vital for supervisors to recognise this fact, and, to work with the resources - including personnel - that one has been given in order to assist and shape supervisees in a way that meets their professional development. In addition, supervision must also be of benefit to all parties involved - the supervisor, the supervisee and ultimately the patients in which they now, and in the future will encounter.[19]

\subsubsection{Planning}

Preparation and planning should be at the centre of each of the actions and processes, particularly within a supervisor-supervisee relationship. Central to the planning phase is to acknowledge that there are power imbalances in the relationship which include, but not limited to, status, knowledge and experience.[20, 22] These imbalances need to be explicitly discussed and negotiated both verbally, and if required, in writing. The development of a contract - verbal or written - will allow both parties to employ appropriate coping strategies and move forward as issues arise. Planning for a worst-case scenario is much like an insurance policy - being aware of obligations, and how to move forward if the need arises.[20, 22, 32]

Planning also includes a consideration of the "who, why and how' the supervision itself is to be conducted in order to meet the needs of both parties, in an efficient manner. Planning is about gathering information both formally and informally, gaining insight into how others practice, and negotiating with staff around allocation, timeframes, and the needs of individual supervisees. Wickham [27] and Senediak and Bowden [22] have suggested asking a number of questions in the planning stage that will guide the practice of supervisors and improve the outcomes of the supervisor-supervisee encounters:

- Is there a local supervision policy? If so, does practice follow the policies?

- Is there a model of supervision that will or should be followed? If so, what does it entail and have both parties agreed on this model?

- Is there an opportunity to have a say in selecting a supervisee?

- Will supervisor-supervisee agree on and sign a contract and will it include a strategy to resolve any difficulties?

- How long will the relationship last?
- How many meetings are planned and of what length?

- What will be the ground rules for meetings, feedback and clinical performance review?

- How will meetings be recorded?

- Whose responsibility is the setting of an agenda for the meetings? Will the agenda include any preparatory reading?

- What tools will be appropriate within the supervision relationship?

- What are the goals outlined from the training organisation that are required to be met by the supervisee, supervisors or organisation?

- What roles does the supervisor undertake to ensure goals are met?

- How will the supervisor and supervisee measure the outcomes of supervision in order to demonstrate its impact on those who they service?

This list of questions is not prescriptive, but rather should be used to facilitate a supervisor-supervisee dialogue toward a better outcome for the encounter. It also provides the basis for other questions that may arise within a supervisor's repertoire over time. It is recommended that supervisors become fully cognisant of the key questions they would like answered before proceeding with supervision. Lastly, it is vital to revisit the discussion and any agreements made with each supervisee regularly to ensure that aims and goals are being achieved and to adjust or make changes when and if required.[21]

\subsubsection{Communication}

Communication is a vital element of supervision and several studies have highlighted the negative implications of failing to provide regular, effective feedback or the inability to communicate clearly and effectively.[27, 30, $33,34]$ Along this line, effective communication will have a large impact on both the supervisor and supervisee. Rather than adopting a dictatorial approach to communication, it is more important to have open and fluid conversations and communication, so that it may not impede the process of teaching, learning, knowledge creation, and skill development. Communication, including regular feedback, ameliorates barriers between the supervisor and supervisee, as both parties come to the relationship with differing levels of power, expectations and also idealised versions of each other. It is through communication that facades or masks of perceptions are removed and both parties can come to understand each other as they really are.[21,35] Communication opens opportunities for greater equability within the working relationship, where beliefs and values can be shared and respected.[6]

Communication opens a conduit between two parties that allows trust and respect to flourish. Without trust and respect, safety and security will be less likely to be felt by supervisees, which can impede the capacity for 
supervisees to learn, develop and grow within their future workforce roles.[36] It has been highlighted that "without these preconditions of safety and trust, supervision is unable to be truly effective and becomes instead, disabling and restrictive"( $p$ 663).[21] This does not mean there is a need for an interpersonal relationship outside the workplace; however, if this occurs both parties must be clear as to the boundaries and expectations that are set inside and outside of the working environment.[30]

Open communication should include the discussion of not only past successes, but also mistakes. It is through these discussions of one's own fallibility that greater learning and depth of appreciation can flourish. The process allows greater communication and knowledge seeking among supervisees, while it seeks to avert shame and ridicule that can create withdrawal, disconnection, and even resentment from the supervisee.[21, 30] This should not be seen as a time for confession of past misbehaviour, misdemeanours or gossip. Rather, this time should be used to highlight what has been learned through a supervisor's own errors and how this may be avoided. Potentially, past examples may be used as a learning opportunity by the supervisee that may otherwise make similar mistakes. Further, self-disclosure of successes and mistakes can assist supervisees to be self-reflective in practice, and is an essential or powerful skill for both parties to develop in their practice.[21] The communication process will need to be guided by a supervisor's own judgement of the situation, what can be learned, and in accordance with local policy and guidelines.

\subsubsection{Modelling}

While communication is vital, a supervisor's role modelling will have the greatest impact on the supervisee's learning 'professionalism'. Role modelling is the "intentional and explicit demonstration of professional behaviour during the course of everyday work; structured, reflective self-examination; and timely and meaningful evaluation and feedback for reinforcement" (p.138).[37] Often coined the 'hidden curriculum', it is through their implicit day-to-day interaction and observation of role models, being other more senior health professionals within a clinical environment, that supervisees develop as health professionals.[37-39]

The positive role model of a supervisor assists to develop professionalism among supervisees. It assists to shape who they will become as health professionals and impact career choices.[40] Positive role modelling should be a main focus among supervisors, raising the need for supervisors to learn to recognise positive behaviours and ways to best to role model these.[41] As supervisees see exemplary behaviours, they are more fully able to recognise their own behaviours and attitudes, which further assists positive changes in behaviour over time.[41] There are a number of core values that role models should seek to emulate in developing a sense of health professionalism in their supervisee's and themselves. These are centred on patient care and include compassion, empathy, altruism and honesty. [42] Other key values include: clinical excellence, good teaching, acquiescence of values, professional demeanour, personal awareness and self-motivation.[43]

Role modelling is a much more complex social process than has been given justice here. However, in many cases, what we do, say, and how we behave is a more powerful way of influencing supervisees. [37, 40] There are a number of recommendations with implications across the various health professions. First, supervisors need to enhance their status as role models, which is centred on developing an awareness of role modelling and explicitly articulating their practice when interacting with supervisees. Secondly, supervisors must be acutely aware of the impact and enthusiasm they have on certain aspects of their role. Third, there needs to be adequate organisational strategies in place to support role modelling excellence and opportunities to develop greater capacity of self as a supervisor. Finally, there is a need for supervisors to communicate and collaborate with each other to develop their own role modelling skills.[40]

The time for 'learning from mistakes' and 'see one, do one, teach one' of role modelling is now long past, and effective supervision is a balance between appropriate oversight and clinical practice, while allowing adequate autonomy among supervisees.[44] For example, role modelling where supervisors remain physically or professionally absent within the health setting will be counterproductive. Similarly, supervisors who take on a significant direct patient care workload can also impede a supervisee's own autonomy and development.[44] The challenge is getting the balance between oversight, direct patient care and autonomy right; however, the process is dependent on patient safety as well as the capacity and capability of the individual supervisee.[45]

\subsection{From Direct Instruction to Self-directed Learning}

As previously outlined, supervision is a balance between appropriate and adequate oversight, clinical practice, and autonomy among supervisees, while being cognizant of patient safety and supervisee capacity and capability.[44] Goldszmidt, Faden [46] have suggested four supervisory styles, including (1) direct care supervision, (2) empowerment supervision, (3) mixed practice supervision, and (4) minimalist supervision. Each of these is based upon patient safety, supervisee clinical capacity and quality of care. Oversight and supervisory practice is initially more stringent and closely monitored depending on patient complexity and volume. However, as clinical competence and capacity of supervisee's increases, the reduction of supervision oversight occurs. For example, minimalist supervision is built upon high 
levels of trust with capable supervisees and a greater delegation of patient care.[36, 46]

The ultimate goal of supervision is independent practice, and there remains a fine line between autonomy and care with supervisory oversight.[32, 47] Too much supervision impedes learner autonomy, while too much autonomy impacts clinical skill development and undermines patient safety.[48] Brydges et al. [49] have indicated that autonomy and supervision should co-exist, where autonomy can be provided, even when being supervised in practice. This approach has been shown to be more effective than 'unsupervised practice', where unsupervised practice may lead to inadequate developmental opportunities to increase competence and teamwork, that inefficiently prepares supervisees for the autonomy required and expected in the post training period.

The challenge is for the supervisor and supervisee to recognise a capacity to undertake greater levels of autonomy while not moving toward unsupervised practice. [50] It remains an ongoing process to ensure that the balance of autonomy and supervision is adequate. This balance is contingent on more than the supervisee's clinical knowledge and skills, and should include trustworthiness of the individual trainee.[36, 50] The dimensions of trustworthiness outlined by Kennedy et al. [50] include supervisees knowledge and clinical skills; their capacity to know their limits; the capacity to make adequate judgements; and being meticulous, reliable, truthful and dependable.

In an ideal world, supervision would run smoothly and issues or challenges would be minimised; however, it is vital to recognise challenges may arise along the way. In cases where supervision has provided more autonomous practice, supervisors may need to be acutely aware of key triggers to reassess a supervisee's progress and adjust autonomy and the degree of supervision provided. These triggers for greater oversight may be issues that arise in clinical situations, issues or concerns being raise by other health care professionals, patients or family members of patients.[50] It is also crucial to acknowledge that supervisees themselves may have concerns for patient safety and other issues when working autonomously. Although they may not seek help or want to indicate that they feel out of their depth, it is vital that they are aware that they can approach supervisors or more senior staff for clarification and questions without fear of reprisal. In some cases, the supervisees themselves are able to know and recognise when they are not practicing safely.[48] Each issue or concern will need to be individually assessed against the supervisee's clinical competence, and how then to move forward together in terms of ensuring the appropriate balance between supervision and supervisee autonomy.[50]

\subsubsection{Oversight Activities}

This brings us to what Kennedy et al. [51] term as oversight activities to ensure that the supervisee's autonomy, competence and clinical learning are achieved, while maintaining patient safety. Four types of oversight have been suggested to be undertaken at particular times of clinical supervision. These include:

- Routine oversight: Activities that are planned in advance and undertaken with the supervisor to ensure quality;

- Responsive oversight: Clinical activities that occur in response to supervisee- or patient-specific issues and can be requested or be triggered by performance;

- Backstage oversight: Activities where the supervisee may not be directly aware, but is to ensure clinical care is being provided within the supervisee's competence; and

- Direct patient care: Activities where a supervisor moves beyond oversight of the supervisee to be actively involved in providing care for a supervisee's patient.

These oversight activities create opportunities for flexible learning, while mitigating issues and challenges that inevitably come with greater autonomy and potential for poor clinical habits to develop, and where supervisees may overvalue their own competence to practice.[49] These activities also ensure that trust can be built and maintained within the supervisor-supervisee relationship, while maintaining a high level of patient care and increasing the responsibility and competence of the supervisee.[36]

In addition, these activities enable a supervisor to adequately examine and understand ongoing performance from the beginning right through to the end of the rotation or time with the supervisee.[36] It allows the opportunity to provide more accurate and clear formative feedback, and identify those areas that may require improvement. To achieve this, contact time needs to be adequate so as to ensure bilateral familiarity, open communication, and trust are built and maintained. As this is achieved, the working relationship becomes more fully formed and allows open and honest questioning and feedback to be provided, while mitigating concerns that may arise from constructive feedback.[36]

\subsection{Feedback and Reflective Practice}

Throughout supervision, reflective questioning and providing feedback remains essential and must be well planned. The process will help the supervisee identify their strengths and weaknesses in their practice, while developing their ability to move forward and achieve new and revised goals.

\subsubsection{Feedback}

There has been some apprehension around providing questioning and feedback to supervisees.[22] For some supervisors, particularly those with little formal training, 
providing feedback to supervisees about clinical practice or professional behaviour that is below the expected level of performance, can be construed as confronting or what some might term 'nerve-wracking'.[21, 22, 52] Supervisors may fear the supervisee's reaction to such feedback, leading to fear of litigation or supervisee complaints and this can impact how and if adequate reflective questioning and feedback is given. As such it is imperative that open communication, both written and verbal, includes discussions about the supervisor's motivations for providing feedback, to ensure that the supervisee receives feedback adaptively and is open to participating in a plan for improvement. Again, if issues arise, the initial planning should resolve many of these issues. However, additional planning may need to occur through the process, whether this is with human resources, training bodies, or local and national bodies. This will all depend on circumstances and the situation. [21, 22, 52]

The supervisor should take confidence that reflective questioning and providing feedback is for the benefit of the supervisee, their future practice, and overall for all future patient care outcomes. Feedback can take many forms and the way feedback is provided is important, such as clearly and constructively articulating the issues, challenges and what worked well can have considerable impact on what can be learned by the supervisee. $[35,53]$ It has been suggested that clear, well thought out, and explicit formative feedback on a regular basis is preferred by supervisees and a much more powerful motivator for change and confidence in practice.[21,52]

There are a number of definitions and variations of what feedback is and actually means within the clinical setting.[54] The 'formative' nature of feedback adds an additional layer of complexity in terms of how feedback may be characterised and what it actually means. It is argued that formative feedback and formative assessment is central to healthcare education and concerned with channelling trainees and students towards meeting expected performance goals.[55]

From an academic viewpoint, formative feedback is "information communicated to the learner [if delivered correctly] that is intended to modify his or her thinking or behaviour for the purpose of improving learning" (p.154).[52] In clinical practice formative feedback has been less clearly defined with no delineated best practice on how it can be achieved[56]; however, feedback within the clinical setting has been suggested to be at least "specific information about the comparison between a trainee's observed performance and a standard, given with the intent to improve the trainee's performance" (p.193).[54]

Formative feedback in the clinical setting may take on a number of features that include being on-going, two-way, meaningful to the situation, be credible, be highly specific, include self-assessment, while providing direction for improvement for the supervisee.[53] The approach used may include oral feedback, individual and group debriefing, reflective reporting, and written reporting, or any combination of these depending on the needs of the supervisee at the time of the feedback.[57] It is through this formative approach that learning can occur, where practice can be altered and improvements are made by both the supervisee and the supervisor. Regardless of the numerous definitions and meanings, supervisors need to determine how and what works for their situation and then to be consistent throughout the trainee's or student's practice.

Feedback can be provided through the regularly planned meetings, where both parties are aware of the agenda and what will be discussed. It is vital these regular meetings use a formative or modifying approach. However, formative feedback can be at any time and, depending on the situation, may be best provided at the time of practice, clinical examination or shortly thereafter, rather than much later after the opportunity to teach has arisen. Other feedback opportunities may be less formalised and may be facilitated or encouraged. For example, peer feedback has been indicated to be a powerful motivator for learners.[55] Supervisors will be aware when these feedback approaches are appropriate, and it is vital to exercise judgement and sensitivity to ensure learning is maximised with the approach that is taken.

\subsubsection{Reflective Practice}

Reflective practice may be encouraged as part of the feedback process, whereby supervisees provide their supervisors with daily written reflections of their practice. Supervisees' reflections and self-appraisals give the supervisors a benchmark to assist in the formulation of high-quality feedback, increasing the likelihood that regular feedback will be provided to their supervisees.[58] This process of reflective practice and self-appraisal also ensures that students benefit by playing an active role in seeking feedback from the supervisor.

Overall, it is through continual formative feedback that supervisors gain an appreciation of how well the supervisee has developed. Through these processes one can ensure that summative or more final assessments are easily made, and a more accurate representation of the supervisee's performance and development over time is determined and/or articulated. [22]

\section{Conclusions}

This work represents a critical review of the available literature concerning clinical supervision in an effort to fully appreciate the diverse nomenclature, definitions and models of supervision in healthcare. The definitional challenges suggest that the search for a single definition that is appropriate for each clinical setting, specialist 
discipline, and is able to inform the various models of clinical supervision that are common in practice is foolhardy. Instead, we suggest that the policy framework that surrounds models of clinical supervision should be informed ultimately by the development of confidence, professional identity and the consolidation of best practice, to ensure patient safety and the best outcomes for the supervisee. While acknowledging that the dynamic nature of clinical supervision means that it is rarely without its challenges, this critical review culminates in the recognition of those key elements required for successful clinical supervision.

Recognising that healthcare services have limited funds to support clinical supervision initiatives, we propose a series of insights distilled from this work that are recognised as central elements of effective clinical supervision that can be easily incorporated into already developed programs. Reflective practice is central to successful clinical supervision models. Providing a supported space for supervisors to recognise the influence of the 'non-tangible' personal characteristics of the interlocutors in the supervision relationship is essential. Becoming aware of the Self and other, and bringing to conscious awareness those micro factors, such as cultural, social background, and inherent idiosyncrasy in each supervisee, will provide a basis for recognising workload pressures, case-mix and for being aware of psychosocial wellbeing of the supervisee through the supervisee-supervisor relationship. Equally, self-reflection is central to the recommendation of professional role modelling behaviours, as well as the review and feedback process.

In the former, the supervisor reflects on and recognises the influence that their behaviour has on the development of the supervisee and in the later informs the capacity of the supervisor and supervisee to identify areas that are open to personal and professional development as well as strategies to address them. Recognising the power imbalance inherent within the supervisor - supervisee relationship and working to overcome it through self-reflection paves the way for constructive, open communication that is empowering for both parties. Developing a shared plan with agreed aims and objectives, timelines and expectations was found to be a key indicator of the overall success of the clinical supervision relationship. The agreed plan forms the touchstone for the supervisor and supervisee to come back to for informing periodic review and feedback. In culmination, having a plan that is agreed upon, that has strategic points for review and feedback, as well as a mechanism for identifying aspects of success will support the supervisor-supervisee relationship to progress from one of dependence to one of independence.

The principles of clinical supervision as a vehicle for the personal and professional development amongst healthcare professionals are enmeshed in the fabric of contemporary healthcare practice. The outcomes from this close exploration of current 'best practice' would suggest that the development of a policy base that mandates the development of an agreed plan that has points of contact between the supervisor and supervisee, inclusive of, structured opportunities for review and feedback, will provide a trajectory for health agencies to pursue that does not impose further on the fiscally constrained sector.

\section{Acknowledgements}

The authors acknowledge the facilities, and the scientific and technical assistance, of the School of Nursing and Healthcare professions at Federation University Australia, including the Wicking Dementia Research and Education Centre and Menzies Institute for Medical Research, University of Tasmania.

\section{REFERENCES}

[1] Fitzpatrick S, Smith M, Wilding C. Quality allied health clinical supervision policy in Australia: a literature review. Aust Health Rev. 2012; 36(4):461-5.

[2] Kilminster S, Jolly B. Effective supervision in clinical practice settings: a literature review. Med Educ. 2000; 34(10): 827-40.

[3] Hore CT, Lancashire W, Fassett RG. Clinical supervision by consultants in teaching hospitals. Med J Aust. 2009; 191(4): 220-2.

[4] Bernard JM, Goodyear RK. Fundamentals of Clinical Supervision. 4th ed. Upper Saddle River, New Jersey: Pearson; 2008.

[5] Cutcliffe JR, Butterworth T. Clinical supervision and clincial governance for the twenty-first cetury: An end or just the beginning? In: Cutcliffe JR, Butterworth T, Proctor $\mathrm{B}$, editors. Fundamental themes in clinical supervision. London: Routledge; 2001. p. 316-22.

[6] Barker ER. Mentoring - A complex relationship. Journal of the American Academy of Nurse Practitioners. 2006; 18(2): 56-61.

[7] Hancox K, Lynch L. Clinical Supervision for Health Care Professionals. Course Guide. Melbourne: Centre for Psychiatric Nursing Research and Practice; 2002.

[8] Hawkins P, Shohet R, Ryde J, Wilmot J. Supervision in the helping professions. Berkshire: McGraw-Hill Education; 2012.

[9] Inskipp F, Proctor B. Becoming a Supervisor. Twicken-ham: Cascade; 2001

[10] Chaves LDP, Mininel VA, da Silva JAM, Alves LR, da Silva MF, Camelo SHH. Nursing supervision for care comprehensiveness. Revista Brasileira De Enfermagem. 2017; 70(5): 1106-11. 
[11] Milne D. An empirical definition of clinical supervision. Brit J Clin Psychol. 2007; 46(4): 437-47.

[12] Fernandez R, Sheppard-Law S, Curtis S, Bancroft J, Smith W. Exploring the experiences of neophyte nurse mentors: A qualitative study. Nurse Education in Practice. 2018; 29: 76-81.

[13] Hesketh EA, Laidlaw JM. Developing the teaching instinct 5: Mentoring. Medical Teacher. 2003; 25(1):9-12.

[14] Launer J. Narrative-Based Supervision. In: Sommers LS, Launer J, editors. Clinical Uncertainty in Primary Care: The Challenge of Collaborative Engagement. New York, NY: Springer New York; 2013. p. 147-61.

[15] Morrison S, Halpern H. Narrative-based supervision. In: Owen D, Shohet R, editors. Clinical Supervision in the Medical Profession: Structured reflective practice: Structured reflective practice. Berkshire: Open University Press McGraw Hill; 2012. p. 47-61.

[16] Miller TW, Miller JM, Burton D, Sprang R, Adams J. Telehealth: A model for clinical supervision in allied health. Internet Journal of Allied Health Sciences and Practice. 2003;1(2):6.

[17] Andersen DS, Cabrera ME, Rojas-Muñoz EJ, Popescu VS, Gonzalez GT, Mullis B, et al. Augmented Reality Future Step Visualization for Robust Surgical Telementoring. Simulation in Healthcare. 2019; 14(1): 59-66.

[18] Kalisch BJ, Falzetta L, Cooke J. Group e-mentoring: A new approach to recruitment into nursing. Nursing Outlook. 2005; 53(4): 199-205.

[19] Goldman S. Enhancing adult learning in clinical supervision. Acad Psych. 2011; 35(5): 302-6.

[20] Pack M. Two sides to every story: a phenomenological exploration of the meanings of clinical supervision from supervisee and supervisor perspectives. J Soc Work Pract. 2012; 26(2): 163-79.

[21] Pack M. Clinical supervision: an interdisciplinary review of literature with implications for reflective practice in social work. Reflective Practice. 2009; 10(5): 657-68.

[22] Senediak C, Bowden M. Clinical supervision in advanced training in child and adolescent psychiatry: a reflective practice model. Australasian Psychiatry. 2007; 15(4): 276-80.

[23] Grant, M. J., \& Booth, A. A typology of reviews: an analysis of 14 review types and associated methodologies. Health Information \& Libraries Journal. 2009; 26(2): 91-108. http://doi.org/10.1111/j.1471-1842.2009.00848.x

[24] Blanchard RD, Visintainer PF, La Rochelle J. Cultivating Medical Education Research Mentorship as a Pathway Towards High Quality Medical Education Research. J Gen Intern Med. 2015; 30(9): 1359-62.

[25] Stoltenberg CD. Enhancing professional competence through developmental approaches to supervision. Am Psychol. 2005; 60(8): 857-64.

[26] Dobrowolska B, McGonagle I, Kane R, Jackson CS, Kegl B, Bergin $\mathrm{M}$, et al. Patterns of clinical mentorship in undergraduate nurse education: A comparative case analysis of eleven EU and non-EU countries. Nurse
Education Today. 2016; 36: 44-52.

[27] Wickham JM. Supervision: an issue for supervisors and supervisees. Adv Psych Treat. 2012; 18(6): 416-7.

[28] HWA. National clinical supervision support framework. Adelaide; 2011 July 2011.

[29] HWA. National Clinical Supervision Competency Resource Adelaide; 2013 May 2013.

[30] Bailey SF, Voyles EC, Finkelstein L, Matarazzo K. Who is your ideal mentor? An exploratory study of mentor prototypes. Career Dev Int. 2016; 21(2): 160-75.

[31] Farnan JM, Paro JA, Higa J, Edelson J, Arora VM. The YouTube generation: implications for medical professionalism. Perspect Biol Med. 2008; 51(4): 517-24.

[32] Cuncic C, Regehr G, Frost H, Bates J. It's all about relationships. Perspectives on Medical Education. 2018; 7(2): 100-9.

[33] Kilminster S, Cottrell D, Grant J, Jolly B. AMEE Guide No. 27: Effective educational and clinical supervision. Med Teach. 2007; 29(1): 2-19.

[34] Macdonald J. Clinical Supervision: A Review of Underlying Concepts and Developments. Aust NZ J Psychiat. 2002; 36(1): 92-8.

[35] Allen L, Molloy E. The influence of a preceptor-student 'Daily Feedback Tool' on clinical feedback practices in nursing education: A qualitative study. Nurs Educ Today. 2017; 49: 57-62.

[36] Hauer KE, ten Cate O, Boscardin C, Irby DM, Iobst W, O'Sullivan PS. Understanding trust as an essential element of trainee supervision and learning in the workplace. Adv Health Sci Educ. 2014; 19(3): 435-56.

[37] Park J, Woodrow SI, Reznick RK, Beales J, MacRae HM. Observation, reflection, and reinforcement: surgery faculty members' and residents' perceptions of how they learned professionalism. Acad Med. 2010; 85(1): 134-9.

[38] Bernard AW, Malone M, Kman NE, Caterino JM, Khandelwal S. Medical Student Professionalism Narratives: A Thematic Analysis and Interdisciplinary Comparative Investigation. BMC Em Med. 2011; 11(1): 1-8.

[39] Carlson E, Pilhammar E, Wann-Hansson C. "This is nursing": Nursing roles as mediated by precepting nurses during clinical practice. Nurse Education Today. 2010; 30(8):763-7.

[40] Passi V, Johnson S, Peile E, Wright S, Hafferty F, Johnson N. Doctor role modelling in medical education: BEME Guide No. 27. Med Teach. 2013; 35(9): e1422-e36.

[41] Curry SE, Cortland CI, Graham MJ. Role - modelling in the operating room: medical student observations of exemplary behaviour. Med Educ. 2011; 45(9): 946-57.

[42] Wyber R, Egan T. For better or worse: role models for New Zealand house officers. New Zeal Med J. 2007; 120(1253): $1-10$.

[43] Byszewski A, Hendelman W, McGuinty C, Moineau G. Wanted: role models - medical students' perceptions of professionalism. BMC Med Edu. 2012; 12(1): 1-9.

[44] Shojania KG, Fletcher KE, Saint S. Graduate Medical 
Education and Patient Safety: A Busy-and Occasionally Hazardous-Intersection. Ann Intern Med. 2006; 145(8): 592-8.

[45] Chun JU, Sosik JJ, Yun NY. A longitudinal study of mentor and protege outcomes in formal mentoring relationships. J Organ Behav. 2012; 33(8): 1071-94.

[46] Goldszmidt M, Faden L, Dornan T, van Merriënboer J, Bordage G, Lingard L. Attending physician variability: a model of four supervisory styles. Acad Med. 2015; 90(11): 1541-6.

[47] Schumacher DJ, Bria C, Frohna JG. The quest toward unsupervised practice: Promoting autonomy, not independence. JAMA. 2013; 310(24): 2613-4.

[48] Kennedy TJT, Regehr G, Baker GR, Lingard LA. 'It's a cultural expectation...' The pressure on medical trainees to work independently in clinical practice. Med Educ. 2009; 43(7): 645-53.

[49] Brydges R, Dubrowski A, Regehr G. A new concept of unsupervised learning: directed self-guided learning in the health professions. Acad Med. 2010; 85(10):S49-S55.

[50] Kennedy TJ, Regehr G, Baker GR, Lingard L. Point-of-care assessment of medical trainee competence for independent clinical work. Acad Med. 2008; 83(10): S89-S92.

[51] Kennedy TJ, Lingard L, Baker GR, Kitchen L, Regehr G. Clinical oversight: conceptualizing the relationship between supervision and safety. J Gen Intern Med. 2007; 22(8): 1080-5.

[52] Shute VJ. Focus on formative feedback. Rev Educ Res. 2008; 78(1): 153-89.

[53] Clynes MP, Raftery SE. Feedback: an essential element of student learning in clinical practice. Nurs Educ Pract. 2008; 8(6): 405-11.

[54] Van de Ridder JMM, Stokking KM, McGaghie WC, Ten Cate OTJ. What is feedback in clinical education? Med Educ. 2008; 42(2): 189-97.

[55] Perera J, Lee N, Win K, Perera J, Wijesuriya L. Formative feedback to students: the mismatch between faculty perceptions and student expectations. Med Teach. 2008; 30(4): 395-9.

[56] Cant RP, Cooper SJ. The benefits of debriefing as formative feedback in nurse education. Aust J Adv Nurs. 2011; 29(1): 37.

[57] Lefroy J, Watling C, Teunissen PW, Brand P. Guidelines: the do's, don'ts and don't knows of feedback for clinical education. Perspect Med Educ. 2015; 4(6): 284-99.

[58] Embo M, Driessen E, Valcke M, van der Vleuten CP. Integrating learning assessment and supervision in a competency framework for clinical workplace education. Nurs Educ Today. 2015; 35(2): 341-6.

[59] Martin P, Kumar S, Lizarondo L. When I say... clinical supervision. Med Educ. 2017; 51(9): 890-1.

[60] Hilli Y, Melender HL, Salmu M, Jonsen E. Being a preceptor-A Nordic qualitative study. Nurse Education Today. 2014; 34(12): 1420-4.

[61] O'Keeffe M, James F. Facilitated group supervision: Harnessing the power of peers. J Paediatr Child H. 2014;
50(12): 944-8.

[62] Undrill G. Incidental supervision. In: Owen D, Shohet R, editors. Clinical Supervision in the Medical Profession: Structured reflective practice: Structured reflective practice. Berkshire: Open University Press McGraw Hill; 2012. p. 62-72.

[63] Tulinius C. "We're All in the Same Boat:" Potentials and Tensions When Learning Through SharingUncertainty in Peer Supervision Groups. In: Sommers LS, Launer J, editors. Clinical Uncertainty in Primary Care: The Challenge of Collaborative Engagement. New York, NY: Springer New York; 2013. p. 241-70.

[64] Morrison S, Halpern H. Peer supervision. In: Owen D, Shohet R, editors. Clinical Supervision in the Medical Profession: Structured reflective practice: Structured reflective practice. Berkshire: Open University Press McGraw Hill; 2012. p. 73-81.

[65] Lekkas P, Larsen T, Kumar S, Grimmer K, Nyland L, Chipchase L, et al. No model of clinical education for physiotherapy students is superior to another: a systematic review. Aust J Physiother. 2007; 53(1): 19-28.

[66] Davis J. The importance of the community of practice in identity development. Internet Journal of Allied Health Sciences and Practice. 2006; 4(3): 1-8.

[67] Severinsson EI. Ethics in clinical nursing supervision-an introduction to the theory and practice of different supervision models. Collegian. 1999; 3(6): 23-8.

[68] Stainsby K, Bannigan K. Reviewing work-based learning opportunities in the community for physiotherapy students: an action research study. Journal of Further and Higher Education. 2012; 36(4): 459-76.

[69] Overton A, Clark M, Thomas Y. A review of non-traditional occupational therapy practice placement education: a focus on role-emerging and project placements. Brit J Clin Psychol. 2009; 72(7): 294-301.

[70] Franklin N. Clinical supervision in undergraduate nursing students: A review of the literature. The E-Journal of Business Education and Scholarship of Teaching. 2013; 7(1): 34-42.

[71] Franklin NF, Leathwick S, Phillips M. Clinical supervision at a magnet hospital: A review of the preceptor-facilitator model. Journal of Nursing Education and Practice. 2013; 4(1): 134.

[72] Borch E, Athlin E, Hov R, Sörensen Duppils G. Group supervision to strengthen nurses in their preceptor role in the bachelor nursing education - Perceptions before and after participation. Nurse Education in Practice. 2013; 13(2): $101-5$.

[73] Finnerty G, Collington V. Practical coaching by mentors: Student midwives' perceptions. Nurse Education in Practice. 2013; 13(6): 573-7.

[74] Aston L, Molassiotis A. Supervising and supporting student nurses in clinical placements: the peer support initiative. Nurse Education Today. 2003; 23(3): 202-10.

[75] Russell K, Hobson A, Watts R. The Team Leader Model: an alternative to preceptorship. Australian Journal of Advanced Nursing. 2011; 28(3): 5-13. 